\title{
DEBORAH HARDY
}

\section{Tkachev and the Marxists}

Interest in Peter Tkachev, the angry young man of the Russian revolutionary movement in the 1860 s and 1870 s, has generally been focused on his role as a "forerunner of Lenin." Indeed, that is what Professor Michael Karpovich called him in an article published several decades ago. ${ }^{1}$ More recently Professor Albert L. Weeks has gone so far as to dub Tkachev "the first Bolshevik."2 In his Tkachev biography Professor Weeks has included a study of similar Soviet opinions, that is, of the great debate in the early 1920s centering on the relationship of Lenin, Tkachev, and Auguste Blanqui, from whom Tkachev drew much of his inspiration.

This apparent Tkachev-Lenin parallel naturally calls forth the question of Tkachev's relationship to the Marxists, those other forerunners of Lenin with whom the Russian critic was acquainted during his own lifetime. Here historical scholarship has been far less certain, Of Tkachev's two biographers, the Soviet historian B. P. Kozmin, who wrote a book on Tkachev's early years in 1922 and later edited his works for publication, overestimates the influence of Marx on Tkachev but does present penetrating studies of the great differences between them. ${ }^{3}$ Professor Weeks in his recent work tends to emphasize "Tkachev's Marxist inclinations," particularly in terms of economic thought," A few early Soviet writers, carried away by their enthusiasm for any prerevolutionary Russian who sounded as revolutionary as Marx, occasionally rather casually called Tkachev a Marxist. Among them was Pokrovsky, writing in $1924 . .^{5}$ By the mid 1930s such references had disappeared into the

1. Michael Karpovich, "A Forerunner of Lenin: P. N. Tkachev," Revieze of Politics, 6 (1944) : 336-50.

2. Albert L. Weeks, The First Bolshevik: A Political Biography of Peter Tkachev (New York and London, 1968).

3. Kozmin wrote prolifically on Tkachev and other radicals of the $1870 \mathrm{~s}$. His book was entitled $P . N$. Tkachev i revoliutsionroe dvizhenie 1860-kh godov (Moscow, 1922). Also to the point are his introductory essay on Tkachev in P. N. Tkachev, Isbrannye sochineniia na sotsial'no-politicheskie temy, 6 vols. (Moscow, 1932-37), 1:9-56 (hereafter this work is cited in the text and footnotes by volume and page numbers), and the article " $\mathrm{K}$ voprosu ob otnoshenii $\mathrm{P}$. N. Tkacheva $\mathrm{k}$ marksizmu," Literaturnoe nasledstvo, 7-8 (1933) : 117-23.

4. Weeks, The First Bolshevik, pp. 129-35 and passim.

5. M. N. Pokrovsky, Ocherki russkogo revoliutsionnogo dvizheniia $X I X-X X$ vv. (Moscow, 1924), p. 62. See also, for example, N. K. Piksanov, Dva veka russkoi literatury (Moscow and Petrograd, 1923), p. 142, and N. Kravtsov, "P. N. Tkachev: Pervyi kritik-marksist," Na literaturnom postu, 1927, no. 3, pp. 22-26. 
strict Stalinist reaction, and the accepted Soviet viewpoint was to associate Tkachev with the populists and emphasize his non-Marxist attitudes.

Indeed, most of these writers have strained to find similarities. Forerunner of Lenin though Tkachev may have been, Marxist or even pro-Marxist he was not. Tkachev respected Marx, although he was not very interested in his ideas. The relationship of the young Russian's thinking to that of Marx is superficial at best, confined to an analysis of capitalism and a vaguely similar view of the importance of economics. On one basic point of disagreement-the possibility of immediate revolution in Russia-Tkachev took the side of the populists and entered into a bitter public polemic with Engels. Moreover, the young Russian had no respect whatsoever for Marx's favored forms of political action, the International and the German Social Democratic Party. In short, although he respected Marx's personal research, Tkachev remained bitterly anti-Marxist in politics throughout his life.

Peter Tkachev admired Marx, but only to a certain degree. The Russian critic was acquainted with Marx's major published works, and he cited two of them in book reviews written in the period (1861-73) before he left Russia: the Critique of Political Economy, which he read in 1865, and the first volume of Capital, 1867 German edition, which he had on hand at least by $1870 .^{6}$ It should be noted, however, that he never devoted so much as a full paragraph in any of his writings to Marxist theory, that he never seems to have tried to master its intricacies, particularly in historical interpretation, nor did he ever trouble to review Marx's works for the Russian press. Like many of his Russian contemporaries, Tkachev devoted far more serious study to the ideas of Bakunin, Proudhon, and Lassalle.

Tkachev's first mention of Marx in the Russian press (in an article published in December 1865) raises the thorniest question because it concerns an area in which the two men's ideas might be thought to coincide-the importance of the role of economics in history and society. In 1865 Tkachev reviewed two books by Iurii Zhukovsky, a writer on a rival magazine. ${ }^{7} \mathrm{Al}-$ though he found Zhukovsky on the whole unsatisfactory, he did approve of the other writer's economically oriented approach to history, and in connection with it he cited with approbation Marx's famous superstructure analogy. The view that economic factors lie at the core of social development is not new, Tkachev wrote,

and it is carried over into our literature, like everything that is good in [our literature], from West European literature. As early as 1859 the

6. These references are found in Tkachev, 1:69-70, 2:148, and 6:161.

7. Ibid., 1:69-77. Zhukovsky wrote for Sovremennik and Tkachev (at this time) for Pisarev's nihilist journal, Russkoe Slovo. 
well-known German exile Karl Marx formulated it in a most exact and definite fashion (Zur Kritik der politischen Ökonomie, pp. iv, v). Now this viewpoint has become almost the common property of all thoughtful, honest. people, and scarcely any intelligent man will find any serious objection to it. ${ }^{8}$

In a footnote he quoted Marx's famous statement from the introduction of Critique and a similar phrase from a later chapter of the same book.

Now Tkachev was always convinced of the importance of economics in social life and historical development. This conviction is probably the main reason scholars have considered him Marxist at all. Economic determinism, of Tkachev's own variety, is indeed the dominant theme of his early writings, although after 1873 it was superseded by consideration of more practical revolutionary problems.

Did Tkachev draw his ideas from Marx? Evidence indicates that he did not. In the first place, his own expression of economic determinism antedates his citation of Marx by several years. In his early articles Tkachev was a great citer of authorities, constantly seeking those who reflected his own feelings. There is little doubt that he would have mentioned Marx as soon as he found him. Indeed, he greeted him in 1865 with the enthusiasm of a new acquaintance, although he hastened to call him a "well-known" figure. Tkachev's own espousal of "economic determinism" had appeared at least two years before he first mentioned Marx, and Marx just served to confirm his views. In an article published in January 1864, dedicated, as most of his first works were, to analysis of law, Tkachev had written: "Positive law, juridical relations comprise one of the aspects of social life. In order to understand this aspect, it is necessary to form for oneself a clear, precise conception of those basic principles and fundamentals which lend tone and direction, so to speak, to all the social life of society. What sort of principles are these? Economic!" $(5: 23)$. He made another, even stronger, statement during the same year, one that bore a resemblance to the Marxian superstructure analogy: "All social life in all its manifestations, with its literature, science, religion, with its political and juridical mores, is nothing other than the product of certain economic principles, which lie at the basis of all these social phenomena" (5:93). But these comments preceded his reference to Marx by more than a year. One must conclude that Tkachev's own outlook was formulated before he ever read Critique.

In the second place, Tkachev's economic determinism-and the term might well be put in quotation marks-is of a totally different breed from that of Karl Marx. To any keen Marxist eye-such as that of the Soviet

8. Ibid., $1: 69-70$. 
economist A. Reuel, who wrote a devastating article on Tkachev's economic theory in the $1930 \mathrm{~s}^{2}$ - something is clearly lacking. It is not always easy to put one's finger on it.

The problem is that Tkachev was scarcely an economist at all, and his economic writings not only lack any systematic approach but even deny that such an approach is possible. The young Russian critic never studied economics intensively. Before he discovered that he had a talent for writing, and made it his profession, Tkachev had studied briefly to be a lawyer. He read Malthus, Adam Smith, Ricardo, and John Stuart Mill more for their humanitarian and sociological implications than for their economic ideas. He scorned economic theory, which he found to be grossly unfair and totally conditioned by the capitalist outlook of its makers. ${ }^{10} \mathrm{He}$ insisted that it was inhumane to allow price to be determined by supply and demand, and he was certain that competition was not a natural tendency of human beings (as capitalist economists insist) but a product of a dog-eat-dog system that would disappear when the system itself was abolished. ${ }^{11} \mathrm{He}$ spent little time considering the essence of value or the relationship of value and price, those favorite nineteenth-century conundrums, and arrived at sketchy, confused conclusions. ${ }^{12}$ He was concerned neither with productive techniques nor with the circulation of money, but centered his economic ideas, as Reuel sarcastically pointed out, not on the making but on the distribution of wealth. ${ }^{13}$

In short, Tkachev was not interested in economics per se. Instead, he falls into those newly defined categories of sociologist and psychologist. $\mathrm{He}$ was concerned with people and their happiness, with classes and their fate rather than with machines and money. His "economic determinism," based as it was on instinct rather than scholarship, boils down to a conviction that men are loyal to their class and act in accordance with their own economic status and benefit, and that the rich pervasively dominate the world. Set forth in careful terms, this set of beliefs can resemble Marx's superstructure analogy; simmered down to specifics, it becomes not economic determinism but environmentalism, not a macroeconomic but a personal-intuitive matter.

Certain of Tkachev's own statements may clarify what $I$ have in mind. A man's outlook, he often wrote, is determined by his class, which is, in turn, frequently a matter of economics. Writers, for example, always let their social status dominate their ideas. For proof Tkachev referred to the "bourgeois"

9. A. Reuel, "Ekonomicheskie vzgliady P. N. Tkacheva," Problemy ekonomiki, 1938, no. 4 , pp. $142-61$.

10. See his review of Malthus, in Tkachev, $5: 446-60$, also $1: 60$.

11. Ibid., $5: 320-26,1: 67$; review of Adam Smith, $5: 391-407$.

12. Ibid., $5: 320 \mathrm{ff}$., $1: 66-67$.

13. Reuel, "Ekonomicheskie vzgliady," p. 148; Tkachev, 5:310-11. 
attitudes of men of the French Enlightenment and the blind acceptance of capitalism and its "laws" by Western economists. ${ }^{14}$ Conditioned by his environment-that is, by his poverty-a poor man thinks differently from a rich one. ${ }^{15}$ Further, in all times the rich have by dint of their wealth imposed their own standards upon society; thus medieval literature reflected the hypocritical mores of chivalry, and feudal lords demanded that wealth be measured only in land. ${ }^{16}$ Hypocritical capitalists, needing freedom to exploit the laboring classes, manage to elevate their purified concept of freedom to a pedestal and impose it upon their societies, although only the rich derive its real benefits. ${ }^{17}$ Tkachev wrote a series of long rambling articles about his native land, identifying the outlooks of different generations with class status (that of the impoverished gentry or the rising raznochintsy, for example), yet it is not economics he is talking-it is a kind of wet-behind-the-ears class psychology. ${ }^{18}$ In every case he belied his own magnificent generalizations. Insisting that the great controlling factor in life and history is economic, he found it instead in psychology, in class allegiance, in environmentalism. His interest was in people, not in abstract economic concepts. Given a purely economic theme, he preferred to drop the subject. He would rather talk humanity. To read Tkachev is to read material miles removed from Capital or Critique.

If Tkachev did not draw his economic ideas from Marx (and no one is more convincing on this point than Reuel), where did he find them? The question is not too difficult to answer, especially in view of the fact that his beliefs basically resemble environmentalism more than economic determinism. The truth is that a kind of socioeconomic determinism, much like Tkachev's, was in the air in St. Petersburg in the 1860s. Zhukovsky provides one example, and Tkachev surely knew his works in Sovremennik long before he formally reviewed them in 1865 . V. D. Spasovich, a professor of law at St. Petersburg where Tkachev went to school and the attorney who defended Tkachev in the Nechaevist trial (1869), had published a textbook denying the absoluteness of law and contending that all law derives from socioeconomic conditions-a book which Tkachev reviewed in 1863 and which may well have influenced his own early article entitled "Juridical Metaphysics" $(5: 15-41)$. Chernyshevsky, the idol of the younger generation and a man Tkachev found occasion to praise, had formulated a similar environmentalism; surely all

14. Ibid., $5: 177-89,312-26,2: 67$.

15. Ibid., $1: 340-41$ and $347-48$.

16. Tkachev was for a time fascinated by medieval history and wrote several long articles about it: see ibid., $1: 101-72$ and $5: 104-52$. In a long essay, not published during his lifetime, he anticipated Max Weber in his identification of Protestantism with capitalism: "Ocherki iz istorii ratsionalizma," 5:104-52, particularly part 2.

17. Ibid., $2: 30-34$.

18. These difficult, unclear, and often contradictory articles were written in 1872 and may be found in Tkachev, $2: 224-57,258-319$, and 320-59. 
young Russian radicals had read Chernyshevsky's Anthropological Principles in Philosophy firsthand in Sovremennik. One of the Western writers that Tkachev reviewed and cited was the German jurist Heinrich Dankwart, whose textbook on civil law indicated the economic basis for legal theory and probably inspired some of Tkachev's own work in his early years. ${ }^{19}$ The young Russian critic himself mentioned his debt to Adam Smith (5:92), who, particularly in the second book of Wealth of Nations, emphasized the importance of economics in society, history, and psychology. Tkachev need not have emulated Marx to have developed intellectually as he did. Almost certainly he drew on other resources-and on his own.

If in his basic premises and world view Tkachev found inspiration elsewhere, he used Marx in another lesser context-to bolster his convictions about the evils of capitalism and bourgeois society. He first cited Marx's Capital (volume 1) in an article written in 1870 while he was in prison (2:148). Indeed, he promised his reader an entire appendix of Marx's statistics on the worker's standard of living. The article was never published, but was confiscated by prison authorities and preserved in the Third Section files, and the appendix was apparently never written out. ${ }^{20}$ At about the same time, in another prison article which also remained unpublished, Tkachev obviously drew on Marx in his description of the depths of capitalistic society. ${ }^{21}$ In lurid detail he portrayed the physical and moral degeneration of the working class, the use of drugs and drink, the deadening effect of the machine, the evils of technological unemployment, and the depreciation of masculine labor with the admission of women and children to the labor market (a problem, incidentally, which he had recognized several years before). ${ }^{23}$ Once more he cited Marx's statistics in regard to the numbers of laborers as compared to accumulation of capital, this time in an article published in 1873 (6:161). $\mathrm{He}$ obviously used the first volume of Capital as a kind of reference book, going to it when he needed information on the degradation of Western society. It should be noted that Tkachev referred always to Marx's statistics, never to his theory or conclusions.

In a myriad other ways Tkachev disagreed with Marx. In many of them he reflects the populist attitudes of his day, on which much has already been written. Suffice it to say, for example, that he was a Benthamite and admired greatly the utilitarian ethic. ${ }^{23} \mathrm{He}$ still believed in the wage fund theory, by

19. Kozmin did not include this review in his collection of Tkachev's works, but he discussed it, with quotations, in 5:470-71, n. 6. Tkachev's references are in $5: 24,41$.

20. See Kozmin's notes 31 and 32, ibid., $2: 443$.

21. Ibid., $6: 5-104$, especially parts 5 through 8 . Similar analyses are found in Marx's Capital, volume 1 , chapter 15 .

22. In 1868. See ibid., $1: 398$.

23. Bentham's ethics, he said, belong "without argument among the greatest and most fruitful doctrines to which human reason at any time has risen." Ibid., 5: 389. 
which any extra money grabbed by the rich automatically came out of the pockets of the poor. ${ }^{24} \mathrm{He}$ thought capitalism would be destroyed not because of any internal contradiction but simply because it did not make people happy. ${ }^{25}$ $\mathrm{He}$ often let his early legal training guide him: he felt that somehow the common man had been deprived of real legal rights, that such rights were now fictional shams, and that society would be set straight again if men got their legal rights back (1:74-75). He heartily disliked all "metaphysical" philosophy and thereby rejected all of Hegel out of hand, never making any exception for the Hegelian dialectic; indeed, he said there was nothing at all worth thinking about in Hegel and called Hegelianism "nonsense."26 Most important, in an age in which great numbers of his contemporaries, not excluding Marx, shared an enthusiasm for the laws by which history unrolled, Tkachev stood firm in his conviction that you cannot find rules for history. Society, he thought, is too full of people, anarchy, whim, and caprice, and it is not like nature at all. He developed an intricate theory of "historical jumps," whereby any society at any time could leave the path it had set forth upon and jump to another, more progressive route. ${ }^{27}$ It is a theory that makes revolution possible in Russia, for Tkachev consistently argued that Russia need not mimic the development of European civilization, need not suffer capitalism at all $(4: 325)$. She could jump crosswise to another, finer path-directly to socialism if she wished.

It is clear that Tkachev was not a Marxist. If in certain ways he was a forerunner of Lenin, it was only insofar as Lenin was different from Marx.

If Tkachev admired Marx, he did nothing but quarrel with Engels. Their public polemic in 1874 anticipated the open arguments between Russian Marxists and populists in later decades. It centered on the issue that dominated Tkachev's activist revolutionary plans: when and how could revolution be made in Russia.

In 1873 Tkachev illegally emigrated abroad to work on Peter Lavrov's journal, Vpered! (Zurich, London). He was sent by a group of young Russian radicals who were disappointed with Lavrov's first issue. This angry young man could not agree with Lavrov, and he had already attacked him bitterly in several published and unpublished works. It was thus a strange move, for it is difficult to believe that Tkachev proposed to change his own views or hoped to change Lavrov's. Perhaps he just wanted to leave Russia,

24. Ibid., $5: 172$, to give one of many examples.

25. Reuel (p. 146) calls this "hairdressing Marx with the comb of Bentham."

26. See Kozmin's note 136, in Tkachev, $3: 473$.

27. See his review of Zimmerman's history of the peasant wars, ibid., 1:234-57. Tkachev's conviction that history does not operate by predetermined laws is most clearly expressed in a long article on Quinet, 2:69-118. See also $1: 69$ and 260-61. 
where his term in exile at Velikie Luki had not yet run out. The two men quarreled before a single issue of the journal had appeared with Tkachev's contributions. Their bitter exchange caught Engels' attention, and he devoted several of his series of articles in Der Volksstaat on the émigré press (1874-75) to Tkachev and his émigré compatriots. ${ }^{28}$

Engels was downright insulting. In his first two articles he sarcastically attacked not just Tkachev but the whole of the Russian émigré colony. These Russians who called themselves revolutionaries were, to Engels, more than a little comical. He derided their affinity for pseudonyms, their long-winded polemics, their bold statements and their cautious actions. His finest scorn he saved for Tkachev, a "green gymnasiast" with "childish, tedious, contradictory views which constantly turn in circles." ${ }^{29}$ Engels set the tone for a bitter, name-calling debate.

In response Tkachev (now living in Zurich) published privately an "Open Letter to Mr. Friedrich Engels," written in German, criticizing Engels' fundamental viewpoints $(3: 88-98)$. To Tkachev's credit, he rose above invective. The gist of his argument was that the situation of Russia was unique-a fundamental populist viewpoint. Engels erred, Tkachev thought, in trying to mold Russian radicalism by reference to the West European experience :

The situation in our country is totally unique; it does not have anything in common with any country in Western Europe. The methods of struggle adopted in the latter are totally and completely unsuited to us. We need a very special revolutionary program, which must differ from the German in the same degree as social-political conditions in Germany differ from those in Russia. To judge our program from a German point of view (i.e., from the point of view of the social conditions of the German people) would be as absurd as to view the German program from a Russian point of view.

Russia, he pointed out, had no urban proletariat, no representative assembly, no highly developed bourgeoisie, no literate lower class, and no free press, all essential to Engels' Western-oriented revolutionism. Broad organization of a workers' movement, of propaganda, and of a socialist party were all impossible in Russia. Tkachev borrowed a phrase from Engels' attack on himself and called any hope for an International of Russian workers a "childish dream."

Nevertheless, Tkachev believed a socialist revolution to be a strong and immediate possibility in Russia. Capitalism, he said, was less highly developed

28. These articles are printed in Karl Marx and Friedrich Engels, Werke (Berlin, 1961), 18: 536-45.

29. Ibid., $18: 542$. 
than in the West, and the task of overthrowing it was thereby made simpler. Moreover, most Russians were instinctively collective-minded. For a critic who frequently attacked idealizers of peasant life, Tkachev could be fairly idealistic himself. He insisted to Engels that the people of Russia "in the majority . . . is permeated with the principles of communal ownership; it, if one may so express it, is communist by instinct, by tradition," again a hallmark argument of the populists of Tkachev's day. It is clear, the young Russian argued in a tone that must have irritated his antagonist, that "our people, in spite of their ignorance, stand much closer to socialism than the peoples of Western Europe, although the latter are better educated than they."

Besides being "instinctively" communistic, the Russian people are "instinctively revolutionary" in spite of their "seeming torpor, in spite of the lack of clear consciousness of their own actions." Tkachev never really decided what he meant by "instinctively revolutionary," and within a few years he was to advance the Jacobin demand for seizure of power by conspiracy on the grounds that popular "instinct" (an idea that sounds like Bakunin) was not enough. He argued to Engels that revolution in Russia would be easy, because the state was so weak: "only from a distance does our government give an impression of power." Unlike the kind of government with which Engels was familiar, firmly rooted in the super-power of a ruling social class, the Russian government was isolated and impotent:

In reality, its power is only apparent, imagined. It has no roots in the economic life of the people, it does not embody the interests of any class. It crushes all social classes equally, and they all equally hate it. . . . In this regard we have a greater chance for victory of the revolution than you do. . . Our social form is obligated to the government for its existence, to a government which hangs, so to speak, in the air, a government which has nothing in common with the existing social strata and the roots of which lie in the past, not in the present.

To Engels' demands that the Russians stop talking and start acting, Tkachev responded with an outline of the difficulty of action in Russia because of the ubiquitous secret police, an attitude which might be said to conflict with his claims that revolution would be easy. To the older man's jeers at Russian émigrés, Tkachev answered that Engels did harm to the international socialist movement by splitting it, by sneering at one of its parts. Tkachev denied his own association (suggested by Engels) with Bakunin, although he went so far as to praise the master Russian anarchist as the revolution's grand old man. Engels later realized his error on this score and admitted that Tkachev (whom he had called a "true Bakuninist") was not an anarchist at all ${ }^{30}$-and

30. Ibid., $18: 663$. 
indeed Tkachev had little in common with any group that proposed to abolish the state.

Engels might have let the argument stand if he had not been urged by Marx to continue the polemic so that it would not seem that Tkachev had won the fight. ${ }^{31}$ In 1875 in five issues of Der Volksstaat he proceeded to attack Tkachev's populist views on the uniqueness of Russia, in regard to capitalism, state, and revolution. ${ }^{32}$ To Engels, very obviously, socialist revolution could take place only after the intensive development of capitalist production and the growth of the bourgeois-proletarian class struggle. It is ridiculous to anticipate such a revolution before the groundwork has been laid, and "a man who can say that this revolution will be easier to accomplish in a country because it possesses no true proletariat and also no bourgeoisie thereby proves only that he still has the ABC of socialism to learn." Contradicting Tkachev, Engels produced a list of classes in Russia from which the government drew support, including the gentry, kulaks, merchants and middle men, the "numerous army of civil servants," and the rapidly developing bourgeoisie, encouraged by railway construction. Indeed, "if $\mathrm{Mr}$. Tkachev assures us that the Russian state has 'no roots in the economic life of the people; it does not embody the interests of any class,' it hangs 'in the air,' it is our opinion that it is not the Russian state which is hanging in the air, but far more Mr. Tkachev."33

Engels denied any uniqueness in the Russian communal spirit. To him the Russians were no more naturally communistic than the peoples of Western Europe, where communal organization once flourished, and the Russian commune, like its Western counterpart, must soon disappear. In Russia, the commune already had "long passed its bloom," and indeed Engels feared that the isolation of one commune from another was serving as "the organic basis for oriental despotism." $34 \mathrm{He}$ also denied that the Russian peasant was "instinctively revolutionary" and pointed out that celebrated Russian peasant-rebels of the past never did seek to destroy the institution of tsardom. Revolution in Russia could never be easy; her past experience proved nothing if not that. Engels' analysis of Russia's situation foresaw a "bourgeois" revolution led by the educated classes with the aim of establishing constitutional government. $\mathrm{He}$ did not deny its value. He merely denied its socialism. Clearly, Engels was insisting that Russia must travel the path of the West and that socialism was a form of economic life that could only follow, and never precede, capitalist development.

31. Ibid., $34: 5$.

32. Three of these articles were published separately by Engels in a little volume entitled Soziales aus Russland (Leipzig, 1875).

33. Marx and Engels, Werke, $18: 557,560$.

34. Ibid., pp. 563-65. 
Tkachev did not answer Engels in a special tract. He did not, however, forget. Later, in his Zurich journal, Nabat, he fired broadside after broadside against the "revolutionaries-reactionaries"-those who for any reason would postpone revolution in Russia. To wait for the development of labor unions, artels, worker federations, or an urban proletariat was putting off revolution, perhaps forever. The Marxist reactionaries

understand that under present economic and political conditions in Russia, a correct and in any wise reasonable organization of workers' groups is absolutely impossible. But this does not disturb them. Why then, they will wait. They do not lack patience! The people's grief, the people's tears are not their grief, their tears! Why should they compromise themselves in risky enterprises? They want to act only when it is a sure thing. It is impossible to act now and be certain. We, all the revolutionaries, understand this very well, and they understand it better than we. But we are not afraid of the risk. Neither we nor the people have anything to regret, anything to lose!

Never in the pages of Nabat did Tkachev mention either Marx or Engels by name.

In spite of its terseness, the public polemic between Tkachev and Engels was far more important than a political squabble about the International, as Professor Weeks sees it. ${ }^{35}$ The disagreement represented a fundamental difference between Marxism and populism. As a populist, at least in this regard, Tkachev argued Russia's uniqueness in the modern world and the possibility of her skipping the capitalist era to plunge directly into a socialist future. Russia, in Tkachev's view, might follow her own destiny, her separate path. By Engels' analysis, there was little unique in the Russian situation except for her backwardness. Russia must travel the road of the West, with communal life disintegrating, capitalism flourishing, and the tsar finally overthrown to make way for constitutional government before any socialist revolution was possible. ${ }^{36}$ The issue was a serious one. Tkachev himself, on the horns of a dilemma, recognized the coming of capitalism to the Russian countryside and thereby conceived his "Jacobin" conviction that revolution must be made at once, even without the peasants' approval. The gulf between Tkachev and Engels was virtually unbridgeable. It took a Lenin to get across it.

One further point of hostility between Tkachev and the Marxists might be mentioned. Tkachev blatantly disliked Marx's practical political schemes. For one thing, he had nothing but jeers for the International and its squab-

35. Weeks, The First Bolshevik, p. 118.

36. Marx later, in his famous letter to Vera Zasulich, himself cast doubt on Engels' interpretation. 
bling, which was in full force at the time he founded his Jacobin journal in the 1870s. True, in 1867 he had published the International's first program, as an appendix to a book he translated into Russian. ${ }^{37}$ It is a measure of his eclectic attitude toward revolutionary cliques that the book was written by a Lassallian and the first appendix consisted of Proudhon's plan for a statesupported bank. Indeed, it is probable that Tkachev was then unaware of the intricacies of the rift between Marx, Proudhon, and Lassalle; possibly he was even unaware that Marx was among the International's founding fathers. By 1873 the International had been broken by the quarrel between Marx and Bakunin, and Tkachev was interested (if at all) only in the anarchist section. ${ }^{38}$ As a theorist he may have respected Marx; as a politician and active revolutionary he chose Bakunin.

In addition to his involvement in the International, Marx was strongly interested in the development of the powerful Social Democratic Party in Germany in the merger of his own adherents with the diminishing forces of Lassalle. Again true to his own beliefs, Tkachev had only scorn for Marx's legitimate political party. He sneered at its dreams of a socialism achieved within a constitutional system as "fantastic illusions and childish enthusiasms" (3:435). Legal political parties could never be revolutionary, not when they were willing to live within society and operate under its laws. Legitimate parties, legally constructed, could be legally destroyed. Moreover, legal political parties would become conservative, they would demoralize real revolutionary instincts, they would develop respect for peaceful progress and would eventually refuse to fight, and their very environment would smother their original ideals. To Tkachev the Social Democrats of Germany were cowards and reactionaries. He held them up to his readers as examples of how not to proceed (3:434-40). If Marx bothered to read Nabat, he must surely have written Tkachev off as the enemy-or possibly, like Engels, as a backward child.

It should be clear that Tkachev was not a Marxist or even a protoMarxist and that he was opposed to most of the basic tenets in Marx's world view. Instead he saw the role of the individual and of human nature in history, the impossibility of isolating laws of historical development, and the importance of the legal rights of man-to cite only a few. Perhaps the most fundamental point of disagreement-at least in 1874-lay in Tkachev's con-

37. The notes and introduction to this translated book, which was by the Lassallian Ernst Becher, may be found in Tkachev, 1:403-29.

38. In his journal, Nabat, Tkachev considered the writings of the anarchists in great detail. On one occasion he reviewed documents from the anarchist section of the International; Tkachev, 3:338-59. He spoke of the English and German sections as "reactionary" (3: 389). 
viction that socialist revolution in Russia could and must come before and not after capitalism. Thereby he argued with Engels, and thereby he became a "Jacobin." An occasional turn of phrase or a superficial resemblance has sometimes deceived investigators, but Marxism as such is simply not there. Perhaps scholars have also been led astray because Tkachev was the most radical, the angriest young man of his day among the Russians-more violent in his outlook than his contemporaries, less compromising in his plans, and seemingly more coldhearted than they. Yet he still belongs with those whom Willian James would call "tender-minded." He would sacrifice logic to believe in revolution, or scholarly research to follow his intuition. His writings show him to be concerned with individuals and human happiness rather than abstract theories. Although he might have denied it, his very approach is from the opposite end of the Marxist pole.

Tkachev was never a Marxist. Lenin may well have been a Tkachevist, or a Blanquist for that matter-but that is another story. 